Christian Guillermet FERNANDEZ

Chairperson-Rapporteur

DOI : $10.14746 /$ ps.2017.1.21

of the Intergovernmental Open Ended-Working Group

on the Right to Peace (2013-15), Geneva

David Fernandez PUYANA

Legal assistant of the Chairperson-Rapporteur (2013-15), Geneva

\title{
IN PURSUIT OF BROAD AGREEMENTS IN THE FUTURE DEVELOPMENT OF THE DECLARATION ON THE RIGHT TO PEACE WITHIN THE UNITED NATIONS
}

On 19 December 2016, the plenary of the United Nations General Assembly (UNGA) in New York ratified the Declaration on the Right to Peace by a majority of its Member States, ${ }^{1}$ as previously adopted by the Third Committee of UNGA on 18 November $2016^{2}$ and the Human Rights Council (HRC) on 1 July $2016^{3}$ in Geneva.

${ }^{1}$ For 131: Afghanistan, Algeria, Angola, Antigua and Barbados, Argentina, Azerbaijan, Bahamas, Bahrain, Bangladesh, Barbados, Belarus, Belize, Benin, Bhutan, Bolivia, Botswana, Brazil, Brunei Darussalam, Burkina Faso, Burundi, Cabo Verde, Cambodia, Cameroon, Central African Republic, Chad, Chile, China, Colombia, Comoros, Congo, Costa Rica, Cote d'Ivoire, Cuba, Democratic People's Republic of Korea, Djibouti, Dominica, Dominican Republic, Ecuador, Egypt, El Salvador, Equatorial Guinea, Eritrea, Ethiopia, Fiji, Gabon, Ghana, Grenada, Guatemala, Guinea, Guinea-Bissau, Guyana, Haiti, Honduras, India, Indonesia, Iran, Iraq, Jamaica, Jordan, Kazakhstan, Kenya, Kiribati, Kyrgyzstan, Kuwait, Lao People's Democratic Republic, Lebanon, Lesotho, Liberia, Libya, Madagascar, Malawi, Malaysia, Maldives, Mali, Mauritania, Mauritius, Mexico, Mongolia, Morocco, Mozambique, Myanmar, Namibia, Nauru, Nepal, Nicaragua, Niger, Nigeria, Oman, Pakistan, Panama, Papua New Guinea, Paraguay, Peru, Philippines, Qatar, Russian Federation, Saint Kitts and Nevis, Saint Lucia, Saint Vincent and the Grenadines, Samoa, Sao Tome Principe, Saudi Arabia, Senegal, Seychelles, Sierra Leone, Singapore, Solomon Islands, Somalia, South Africa, South Sudan, Sri Lanka, Sudan, Suriname, Swaziland, Syrian Arab Republic, Tajikistan, Thailand, Togo, Trinidad-Tobago, Tunisia, Uganda, United Arab Emirates, United Republic of Tanzania, Uruguay, Uzbekistan, Vanuatu, Venezuela, Viet Nam, Yemen, Zambia and Zimbabwe. Against 34: Australia, Austria, Belgium, Bosnia and Herzegovina, Bulgaria, Canada, Croatia, Czech Republic, Denmark, Estonia, Finland, France, Germany, Hungary, Ireland, Israel, Japan, Latvia, Lithuania, Luxembourg, Malta, Monaco, Montenegro, Netherland, New Zealand, Republic of Korea, Romania, Slovakia, Slovenia, Spain, Sweden, the Former Yugoslav Republic of Macedonia, United Kingdom and United States of America. Abstentions 19: Albania, Andorra, Armenia, Cyprus, Fiji, Greece, Iceland, Italy, Liechtenstein, Norway, Palau, Republic of Moldova, Poland, Portugal, San Marino, Serbia, South Sudan, Switzerland and Turkey.

${ }^{2}$ A/C.3/71/L.29, 18 November 2016. The resolution was presented by the following States: Algeria, Bolivia (Plurinational State of), Cuba, the Democratic People's Republic of Korea, Eritrea, Namibia, Nicaragua, the Syrian Arab Republic, Venezuela (Bolivarian Republic of) and Viet Nam. Subsequently, Belarus, Cameroon, the Central African Republic, China, the Lao People's Democratic Republic, Myanmar, South Africa, Togo and Zimbabwe joined in sponsoring the draft resolution. At the same meeting, Benin, Colombia, Costa Rica, Ecuador, Egypt, El Salvador, Ghana, Indonesia, Nigeria, Paraguay, Senegal, the Sudan and Uganda joined in sponsoring the draft resolution, as orally revised.

${ }_{3} \mathrm{~A} / \mathrm{HRC} / 32 / 28,1$ July 2016. 
In the adoption of the Declaration on the Right to Peace by the UNGA Third Committee, the mobilization and strong voice of some civil society organizations was properly heard in its $71^{\text {st }}$ session, when they openly called on Member States to take a step forward by adopting a declaration that can be meaningful for generations to come.

The resolution A/C.3/71/L.29 of the UNGA Third Committee, in which the Declaration was annexed, includes in its operative part as a new element a general reference to the previous resolutions adopted by the General Assembly on "the promotion of peace as a vital requirement for the full enjoyment of all human rights by all." The last resolution on this topic (A/RES/69/176, 2015) not only reaffirms that the peoples of our planet have a sacred right to peace, but also welcomes the decision of the HRC, in its resolution 20/15, to establish an open-ended intergovernmental working group (OEWG) with the mandate of progressively negotiating a draft United Nations declaration on the right to peace.

Although most of the States supported the on-going process on the right to peace within the HRC in Geneva, some of them have not recognized the existence of the right to peace under international law. However, they were very open to the approach and procedure proposed by the Chairperson-Rapporteur Ambassador Christian Guillermet-Fernández of Costa Rica and consequently, actively participated in the three consecutive sessions of the OEWG in Geneva.

Thanks to this approach, a majority of Member States supported the Declaration on the Right to Peace and an important number of Western States abstained for the first time ever on this topic at the Third Committee. In fact, this Declaration is the clear result of three years of work with all stakeholders, including civil society. This positive approach was elaborated in light of the following elements: firstly, international law and human rights law; secondly, the mandate of the HRC in the field of human rights and thirdly, the human rights elements elaborated by the resolutions on the right of peoples to peace adopted by the HRC in the past years.

An agreement among States and regional groups could not finally be achieved within the HRC and the Third Committee, exclusively because of the lack of agreement on the title and Article 1 of the text as presented by the Chairperson-Rapporteur on 21st September 2015. However, as indicated by a Group of States ${ }^{4}$ within the Third Committee, the Declaration has some value because it develops the New Agenda 2030 and also reinforces the three UN pillars - peace and security, development and human rights. Also they pointed out that the Preamble of the Declaration additionally contains many elements that will benefit the clarity and greater balance in order to ensure and to represent the full range of views among memberships.

This paper shall introduce the reader to the last discussions and debate on the right to peace within the Third Committee to understand how divisions on the title and article 1 could be interpreted in the future in order to constructively continue this discussion. Additionally, this article shall analyze the current conflicting areas on this issue; taking into account other difficult UN processes, such as the adoption of the Declaration on the Establishment of a New Iernational Economic Order in 1974. Some ideas intended to overcome the differences will be raised. Finally, it shall be concluded that

\footnotetext{
${ }^{4}$ Australia, Liechtenstein, New Zealand, Norway, Switzerland and Iceland.
} 
in accordance with UN practice, Member States tend to work within the General Assembly on the basis of broad agreements.

\section{ROLE PLAYED BY CIVIL SOCIETY ORGANIZATIONS}

After the adoption of the Declaration on the Right to Peace by the HRC on 1 July 2016, the Foundation Culture of Peace delivered a statement in which they stressed that in order to promote the right to peace, it is imperative to implement the Declaration and Programme of Action on a Culture of Peace. They also stressed in their statement that "the UNESCO initiative in which in 1997 Member States were invited to discuss a draft Declaration on the Human Right to Peace soon will be realized within the General Assembly."

The UNESCO Chair on Human Rights, Democracy and Peace at the University of Padova (Italy) in a legal study about the Declaration adopted by the HRC concluded in November 2016 that the conjunction of Article 1 with the very title of the Declaration presupposes that a human right to peace does already exist as implicitly proclaimed by Article 28 of the Universal Declaration of Human Rights: "Everyone is entitled to a social and international order in which the rights and freedoms set forth in this Declaration can be fully realized."

As suggested by the Foundation Culture of Peace, on 18 November 2016 the UNGA Third Committee adopted a Declaration on the Right to Peace. This Declaration will pass to the UN history for being the first peace Declaration adopted by the General Assembly in this new Millennium. Consequently, the mobilization and strong voice of some civil society organizations was properly heard in its $71^{\text {st }}$ session. In particular, on 2 September 2016 the International Association of Peace Messenger Cities adopted the Wielun Declaration in Poland by which they welcomed the adoption by the HRC of the Declaration on the Right to Peace contained in the annex to its resolution 32/28 and called upon the General Assembly of the United Nations to adopt this Declaration by consensus.

Additionally, the Human Rights Centre and the UNESCO Chair at the Padova University informed that they had promoted and carried out, with the collaboration of the National Coordination of Local Authorities for Peace and Human Rights, a large campaign in Italy, to support the work of the United Nations. They added that more than 300 City Councils and 5 Regional Councils had adopted a petitionary motion in this regard.

An important group of civil society organizations stressed in an Open Letter of November 2016 addressed to the diplomatic community that: "in today's world, devastated by armed conflicts, hate and poverty, the recognition and declaration by an overwhelming majority of states that 'Everyone has the right to enjoy peace,' would send to Humanity, and in particular to young and future generations, a very much needed message of peace and hope ... The adoption of the UN Declaration on the Right to Peace will represent a little step forward toward the fulfilment of the solemn promises we made in 1945."

${ }^{5}$ This letter was prepared by the International Association of Democratic Lawyers (IADL), Comunità Papa Giovanni XXIII (APG23), UN Network of United Network of Young Peacebuild- 
In parallel, the Chairperson of the Drafting Group on the right to peace at the Advisory Committee (AC) of the HRC, Ms. Mona Zulficar, and the Chairperson-Rapporteur of the OEWG at the HRC, Ambassador Christian Guillermet-Fernández, published in the Arab newspaper Elaph in December 2016 a reflection in which they stressed that the OEWG witnessed that the text presented by the AC was not properly supported by Member States. For this reason, the Chairperson-Rapporteur decided to promote the effective implementation of the Declaration and Programme of Action on a Culture of Peace, taking into account that all the main elements on the right to peace identified by the AC had been elaborated in the Programmes of Action on Vienna and Culture of Peace.

Finally, on 22 October 2016, Paz sin Fronteras (PSF), created by Mr. Miguel Bosé and Mr. Juanes, began the campaign called \#RightToPeaceNow by which well-known personalities urged Member States of the Third Committee of the General Assembly to adopt a Declaration on the Right to Peace at the end of the 71th regular session. During this campaign, several personalities of the world of culture and art raised their voices to demand a Declaration on the Right to Peace through their media and social networks. They expressed their support so that the process was definitively closed in New York with the adoption of a Declaration on the Right to Peace, such as occurred in this case.

\section{MEMBER STATES}

The resolution A/C.3/71/L.29, in which the Declaration was annexed, was presented by the delegation of Cuba. In its presentation, they said that the adoption of this text is a moral imperative and that they are encouraged by the willingness to contribute to raise awareness among people and governments about the different elements which compose the right to peace at a time when world peace is the desire of millions of

ers (UNOY) and Japanese Committee for the Human Right to Peace (JCHRP) and it was supported by: Foundation Culture of Peace, International Society for Human Rights (ISHR), Finn Church Aid (FCA), International Federation of Settlements and Neighbourhood Centers (IFS), Commission Africaine des Promoteurs de la Santé et des droits de l'homme (CAPSDH), Cultura de Solidaridad Afro-Indígena, International Organization for the Elimination of All Forms of Racial Discrimination (EAFORD), Universal Esperanto Association (UEA), Mother's Legacy Project, International Federation of Women in Legal Careers (IFWLC), International Federation of Women Lawyers (IFWL), 3HO Foundation, Institute for Planetary Synthesis (IPS), Institute of Global Education, Lama Gangchen World Peace Foundation, Federation of Family Associations of Missing Persons from Armed Conflicts (IFFAMPAC), Pax Christi International, Foundation for GAIA (GAIA), Planetary Association for Clean Energy (PACE), Global Eco-village Network (GEN), Institute of International Social Development at the United Nations (IISD), International Association of Peace Messenger Cities (IAPMC), International Peace Bureau (IPB), World For World Organization (WFWO), United Religions Initiative (URI), Lucis Trust-World Good Will Bangwe and Dialogue, Dzeno, Istituto Internazionale Maria Ausiliatrice delle Salesiane di Don Bosco (IIMA), Foundation for the Refugee Education Trust (RET International), Graines de Paix, International Volunteerism Organisation for Women Education Development (V.I.D.E.S.), US Federation for Middle East Peace, ONG Hope International, World Association for Education as an Instrument of Peace, Commission Colombian of Jurist, General Arab Women Federation (GAWF), International Organization for Victim Assistance (IOVA), International Society for Traumatic Stress Studies (ISTSS), International Women's Year Liaison Group, Association Points-Coeur, Nonviolent Peaceforce, Association Centre Europe - Tiers Monde Cetim. 
people. By adopting this declaration, they said, we aspire to send a clear message of commitment and protection of the right to peace and the lives of millions of people.

The United States of America pointed out that they do not agree with the attempts to develop the collective right to peace because it modifies the circle of the exercise of the existing human rights. Consequently, they decided to call the vote and vote against this resolution. Japan considered premature to recognise peace as a human right principle since it has not been established under international law. They said that the adoption of this resolution at the third committee without reaching consensus among Member States, following the same case as in Geneva, is regrettable. Iran indicated that the maintenance and global realization of the right to peace needs a holistic approach. Unfortunately, they added, some important requirements for the realization of the right to peace, such as the challenges posed by the arms of mass destruction to the international peace and security was totally overlooked in the Declaration.

The European Union said since the establishment of the OEWG on the right to peace, three years ago, they have consistently expressed their willingness to engage in the discussion between the linkage of peace and the enjoyment of human rights, with a view to reach a consensus on the draft declaration. According to them, the WG has been a model of cooperation and open dialogue. All sides proved their willingness to have a possible consensus on a declaration acceptable to all. However, in spite of all efforts, consensus was not possible. There is neither an agreed upon definition of peace nor agreement as to who will be the right-bearers and duty-bearers of such right. In addition, the proposed declaration could be contrary to some provisions of the UN Charter. Finally, the absence of peace cannot justify the failure to respect human rights. Under these circumstances, they reaffirmed that they are not in the position to support this draft resolution.

Iceland, on behalf of a Group of States, ${ }^{6}$ recalled that it is clear that sustainable development cannot be realized without peace and security, and peace and security will be at risk without sustainable development. The New Agenda 2030 recognise the need to build peaceful just and inclusive societies and provide equal justice, the protection and respect of human rights, the effective rule of law and governance in all levels and in transparency and effective and accountable institutions. Consequently, they added that they are all committed to the Global Agenda 2030 and to goal 16 on the promotion of peaceful and inclusive societies for sustainable development for all. The 2030 Agenda states that we are determined to foster peaceful, just and inclusive societies which are free from fear and violence. There can be no sustainable development without peace and no peace without sustainable development. However, they also indicated that they are not in the position to support in this point this draft resolution, because there is not a common legal understanding for the specific right to peace and is also unclear who will be the right-bearers or duty holders of such right.

Finally, Liechtenstein, on behalf of another Group of States, ${ }^{7}$ indicated that the Charter of the United Nations rests on principles of the United Nations, which are,

${ }^{6}$ Australia, Liechtenstein, New Zealand, Norway, Switzerland and Iceland.

${ }^{7}$ Austria, Belgium, Costa Rica, El Salvador, Estonia, Iceland, Latvia, Lithuania, Luxembourg, Poland, Slovenia, Switzerland and Liechtenstein. 
inter alia, to maintain peace and security and to that end to take effective and collective measures for the prevention and removal of threats to peace and for the suppression of acts of aggression or other breaches against peace. They added that the step was taken when States parties to the International Criminal Court (ICC) Statute adopted by consensus provisions on the crimes of aggression, which were included in the Kampala Review Conference in 2010. The activation of the Kampala process in 2017 will constitute a historic step in order to stop illegal wars and for them, this is a main contribution to the cause of peace.

\section{CONSENSUS WITHIN THE GENERAL ASSEMBLY}

Although an agreement among States and regional groups could not finally be achieved within the HRC and the Third Committee, exclusively because of the lack of agreement on the title and Article 1 of the text, some opposing Member States to the notion of the right to peace pointed out that the Declaration has some added value.

As recognised by some Groups of States ${ }^{8}$ the Declaration on the Right to Peace correctly reinforces the Global Agenda 2030 and its goal 16 on the promotion of peaceful and inclusive societies for sustainable development for all. In addition, this Declaration reaffirms that peace and security, development and human rights are the pillars of the United Nations system and the foundation for the collective security and well-being as well as that development, peace and security and human rights are interlinked and mutually reinforcing.

Another Group of States ${ }^{9}$ stressed that one of the key contributions to promote peace is therefore to complement the provisions of the UN Charter, which regulates the legality of the use of force with provisions that establish individual criminal responsibility for the crimes of aggression. Therefore, they called upon all Member States, in particular the supporters of the Declaration on the Right to Peace to ratify the Rome Statute and the Kampala amendments to ensure that the perpetrators of crimes of against peace are held accountable.

Consequently, in the line of the voice raised by many civil society organisations, today much more than ever it is necessary that a serious assessment be conducted by all as to whether the international community is in a position to further develop the Declaration on the Right to Peace adopted by the UNGA Third Committee in a more consensual manner within the United Nations.

To respond to this question, we should take into account that in accordance with the doctrine, many times the use of consensus can also be a way of covering up with ambiguities in the text the failure to reach specific agreements on a particular subject. This technique avoids deepening the existing differences among all actors with the pretext of protecting the general interests of all parties implied in the negotiation process. The oral statements delivered by parties prior to the adoption of the text could even be used as evidence of the lack of international custom (Jiménez Cortes, Bondia García, 2010: 105).

\footnotetext{
${ }^{8}$ Australia, Liechtenstein, New Zealand, Norway, Switzerland and Iceland.

9 Austria, Belgium, Costa Rica, El Salvador, Estonia, Iceland, Latvia, Lithuania, Luxembourg, Poland, Slovenia, Switzerland and Liechtenstein.
} 
It should be recalled that this technique was successfully used by States in the adoption of Resolution 3201 (S-VI) on the Establishment of a New International Economic Order in 1974. This resolution was adopted without a vote by the General Assembly, but the statements made by 38 delegates showed clearly and explicitly what was the position of each main group of countries. It follows that despite enormous differences among all regional groups consensus could be achieved.

This important precedent intended to obtain an agreement based on dialogue, transparency, consensus, inclusiveness and objectivity could serve as a good model or practice for other similar processes, whose positions can seem absolutely irreconcilable at certain points. A clear example on that is the lack of agreement on the title and article 1 of the Declaration on the Right to Peace.

In the context of the discussion about the Establishment of a New International Economic Order, the Latin American Group said that consensus, as it has always been understood in the Assembly means that the delegations, in the spirit of compromise, have agreed to a certain degree of sacrifice of the respective positions of their countries in order to arrive at a common agreement (A/PV. 2231, 2.051974: para. 122).

Consensus is not unanimity within the General Assembly (A/PV. 2230, 2.05.1974: para. 182). In light of this approach what conflicting parties can achieve could be described as a collective acquiescence in most of the documents approved. They can avoid confrontation or even the vote, and to that extent they are together. But it would be wrong for anyone to assume that the avoidance of a vote is necessarily the same thing as total agreement (A/PV. 2231: para. 30). However, despite the reservations expressed by delegations, the adoption by consensus of an international instrument marks an important step to obtain substantial agreements on a set of guidelines for future action that would give the United Nations a central role (A/PV.2231: para. 93). Consequently, consensus can be arrived at in the Assembly on the procedures adopted for their preparation and approval (A/PV. 2231: para. 52).

Those reservations could tend not only to reduce the effectiveness of this hard-worked for consensus but to render it inoperative (A/PV. 2230: para. 149). However, these reservations and clarifications can many times be seen as an accessory way, with the idea that the international community would achieve a final grand consensus (A/PV. 2230: para. 165). In this sense, what is intended in this type of process is a consensus procedure, but delegations are also aware that objections at the last second would only serve to exacerbate the divisions that delegations have worked to the best of their ability to bridge during the past weeks, months or years (A/PV. 2230, 1 May 1974: paras. 79-80).

Thanks to this consensual approach, Member States can demonstrate a spirit of co-operation that is greatly encouraging. They make sacrifices with the aim of creating a solid foundation for the forthcoming efforts to design a more just and equitable relationship between nations (A/PV. 2230: para. 124). Additionally, consensus constitutes a very real encouragement for the future and gives reason to hope that the international community can achieve in the United Nations a genuine international solidarity on those fundamental problems with which this General Assembly has had to deal (A/PV. 2230: para. 174).

These broad agreements do not exclude that the hard work can continue long after the process is over. Those legal instruments adopted by consensus constitute an important 
foundation upon which to continue the process of the creation of a more just international order in keeping with the general interests of mankind (A/PV. 2231: para. 56).

In light of this relevant precedent, the two key compelling elements necessary to work in a more consensual manner on those conflicting issues, in which the international community is today still strongly divided, would be the following: 1. Explanation of position of States. 2. The use of ambiguous or vague language in those controversial issues.

\section{PURSUING FUTURE AGREEMENTS}

\section{A. Conflicting points - Title}

In this discussion it would be important to recall that the Security Council Resolution 1860 of 2009 reaffirms in its last preambular paragraph "the right of all States in the region to live in peace within secure and internationally recognized borders" (Resolution 1860, 2009: Preambule). This Council Resolution is based on resolution 242, which was unanimously adopted under Chapter VI in 1967 . The resolution was sponsored by the British ambassador Lord Caradon and was one of five drafts under consideration.

During the debate of this resolution the representative of India stated that "there was considerable agreement on the principle that every State has the right to live in peace and complete security free from threats or acts of war and consequently all States in the area should terminate the state or claim of belligerency and settle their international disputes by peaceful means."

Additionally, the representative of France and Argentina added that they were glad to see that the resolution stresses the second principle, the right to live in peace within its own boundaries. In this case, the "right to live in peace" is principally devoted to the relationship among countries without referring properly to international human rights law. This notion is principally referred to the principles included in Art. 2 of the Charter. ${ }^{10}$

However, the General Assembly also recognized the human rights approach of the right to live in peace in 1993 (res. 48/126). In particular, Art. 1.4 of the UNESCO Declaration of the Principles of Tolerance states that "human beings, naturally diverse in their appearance, situation, speech, behaviour and values, have the right to live in peace and to be as they are."

In other to advance positively on this first challenge, those regional groups which do not accept the notion of the right to peace in the title of the Declaration could carefully study with the other political groups how they could link this latter notion to three pillars of the United Nations - peace and security, human rights and development. They could always deliver an explanation of position on this specific point. In fact, the

${ }^{10}$ Prohibition of the threat or use of force against the territorial integrity or political independence of any State; settlement of international disputes by peaceful means; prohibition to intervene in matters within the domestic jurisdiction; cooperation among States; self-determination of peoples and sovereign equality of States. 
Russian Federation clearly stated on 1 July 2016 that the right to peace is closely connected to peace, human rights and development.

The three UN pillars have been recognized by the HRC as a fundamental element aimed at promoting the right of peoples to peace. In particular, resolutions 11/4 of $2009,14 / 3$ of 2010 and 17/16 of 2011 have constantly stressed these pillars in operative sections. They emphasize that peace and security, development and human rights are the pillars of the United Nations system and the foundations for collective security and well-being. Therefore, it follows that the three UN pillars are strongly linked to the issue of the right of peoples to peace.

The resolution 60/251 of the HRC adopted by the General Assembly on 15 March 2006 recognized in its preambular paragraph 6 that "peace and security, development and human rights are the pillars of the United Nations system and the foundations for collective security and well-being, and recognizing that development, peace and security and human rights are interlinked and mutually reinforcing." (Resolution, 2006: Preambule).

On 21 August 2014, the General Assembly adopted the resolution 2171 by which it expressed its deepest concern about the high human cost and suffering caused by armed conflicts and also recognized that peace, security and development are mutually reinforcing, including in the prevention of armed conflict (Resolution, 2014: preambular paragraph 12).

Seventy years ago, the UN Charter established the three founding pillars of the United Nations: peace and security, human rights and development. Since 1945 these pillars have provided the framework for the United Nations to tackle important challenges. We cannot pick and choose which pillar the United Nations should support, nor can we focus on one to the detriment of the others. To do so would be to ignore the lessons of the past 70 years, and to invite future conflicts.

\section{B. Conflicting points - Article 1}

The first article of the Declaration on the Right to Peace adopted by the HRC states that "everyone has the right to enjoy peace such that all human rights are promoted and protected and development is fully realized." The legislator has desired to understand this provision as the right of everyone to enjoy the three UN pillars - peace, human rights and development.

In order to move towards a consensual outcome using a more ambiguous and vague language, the ASEAN States and many civil society organizations have always advocated for the notion of the right to enjoy peace. This proposal of language was made by Indonesia during the third session and obtained the support from Malaysia, India, Venezuela, Pakistan and Philippines. Additionally, on 25 June 2015, Vietnam on behalf of ASEAN ${ }^{11}$ delivered a statement in which they recalled art. 38 of the 2012 ASEAN Human Rights Declaration which states "every person and the peoples of ASEAN have the right to enjoy peace..."

${ }^{11}$ Brunei Darussalam, Cambodia, Indonesia, Lao PDR, Malaysia, the Philippines, Singapore, Thailand and Vietnam. 
This proposal also received the support from some civil society organizations. On 22 September 2015, an important NGO network called “...on Member States to take a step forward in the promotion of peace by adopting a declaration that proclaims the human right to peace, or at least the "right to enjoy peace."12

It is interesting to highlight that, with this provisions assertion of the right to enjoy peace, human rights and development, the notion of "peace" "human rights" "development" is read in conjunction with the "the right to enjoy." According to the Black's Law Dictionary, the expression "enjoyment" is defined as the "possession and fruition of a right, privilege or incorporeal hereditament," and synonymous with "comfort, consolation, contentment, ease, happiness and satisfaction." It thus follows that "peace," which this document inexorably links to the idea of "enjoyment," can be understood either as a right of all people, or as an aspiration or privilege to be reached by all humankind.

The notion of enjoyment has been used in some relevant legal instruments, such as the International Covenant on Economic, Social and Cultural Rights (Art. 15.3), International Covenant on Civil and Political Rights (Art. 27) and the Council of Europe's Convention on Human Rights and Biomedicine (Preamble).

Additionally, in the context of the thirty-third session, on 16 September 2016, the Core State Group ${ }^{13}$ of the resolution "Cultural rights and the protection of cultural heritage" used the notion of enjoyment in its article 1 as follows: "calls upon all States to respect and protect the right of everyone to access and enjoy cultural heritage" (Art. 1).

It should be confirmed that the inclusion of the right to enjoy peace, human rights and development - three UN pillars - in legal documents is intended to ensure that authorities take measures to guarantee that peace, human rights and development may be enjoyed in a natural and dignified manner. Nevertheless, we note that "peace" is a holistic concept that extends beyond the strict absence of armed conflicts; it is also linked to the eradication of structural violence that results from economic and social inequalities, and to the effective and indiscriminate respect for all human rights and development.

Some experts affirm that the right to peace is deeply rooted in article 28 of the Universal Declaration of Human Rights (UDHR), which states that "Everyone is entitled to a social and international order in which the rights and freedoms set forth in this Declaration can be fully realized." It should be noted that in this provision the legislator uses the

${ }^{12}$ On 22 September 2015, Associazione Comunità Papa Giovanni XXIII delivered a joint oral statement in item 5 on behalf of the Resource Center for Palestinian Residency and Refugee Rights (BADIL), Center for Global Nonkilling, Commission Africaine des Promoteurs de la Santé et des Droits de l'homme (CAPSDH), Institute for Planetary Synthesis, Institute of Global Education, International Association of Democratic Lawyers (IADL), International Network for the prevention of elder Abuse (INPEA), International Peace Bureau, International Society for Human Rights, Instituto Internazionale delle figlie di Maria Ausiliatrice (IIMA), Mothers Legacy Project, Organisation pour la Communication en Afrique et de Promotion de la Coopération Economique Internationale (OCAPROCE), International Pan Pacific Southeast Asia Women's Association International (PPSEAWA), Pax Romana, United Network of Young Peacebuilders, Volontariato Internazionale Donna Educazione Sviluppo (VIDES) and Women's World Summit Foundation.

${ }^{13}$ Cyprus, Greece, Poland, Mali, Switzerland, Ethiopia, Qatar, Ireland and Serbia. 
notion of "entitlement" rather than "right", because they understand that it would be more linked to another notion of "benefit". In this sense, although the expression "benefit entitlement" is often used, the word "benefit" is superfluous in this provision, as "entitlement" is used to refer to a guarantee of access to benefits based on established rights or by legislation (Garner, 2014). The use of "entitlement" rather than "right" in Article 28 should be understood in the context of the debate on justiciability and legal consequences of this provision held among delegations during the drafting process of the UDHR (Schabas, 2013). Some delegations proposed the deletion of this article - Ecuador, Norway and Saudi Arabia - arguing that it was quite impossible for any individual to lay claim in an effective manner the right granted in this provision - Ecuador - and that it was rather tenuous in meaning and failed to confer any specific right - Norway and China.

On the other hand, other delegations underscored that while the first twenty-five articles of UDHR dealt with individual rights, the current article is concerned with general principles and it set forth the ultimate conditions necessary for the realization of those rights - Lebanon. Certain preliminary conditions, such as a social and international order, had to be laid down to ensure the implementation of the rights contained in the Declaration - France. Other delegations stated that this article was drafted as an umbrella article and as a compromise measure to avoid specific reference to the duties of the State - New Zealand. Therefore, as said by some delegations, it should he understood from the perspective that the individual had the right to the implementation of all the articles of the declaration - URSS.

As indicated by Prof. Eide, "some might say that article 28 is a utopian aspiration. It is preferable, however, to see it as a vision to be pursued with determination, while taking into account that it will only gradually and partially be achieved in practice ... Article 28 deals with the process of realization" (Eide, 1999: 597-604). He also says that this provision requires that "social and international conditions be so structured as to make possible the equal enjoyment throughout the world of all the rights listed" (Alfredsson, Eide, 2004: 597). Consequently, this provision refers to the transformation of ideals into normative standards (ibid.: 606).

Like the right to enjoy peace, human rights and development as contained in the Declaration on the Right to Peace, Art. 28 corresponds to the vision of peace, human rights and development underlying the creation of the United Nations. In particular, Art. 55 of the UN Charter states that "... to achieve international co-operation in solving international problems of an economic, social, cultural or humanitarian character, and in promoting and encouraging respect for human rights and/or fundamental freedoms for all without distinction as to race, sex, language, or religion."

In order to avoid the justiciability of environment law, the international community as a whole decided to use the notion of "entitlement" in principle 1 of the Rio Declaration on Environment and Development of 1992 as follows: "Human beings are at the centre of concerns for sustainable development. They are entitled to a healthy and productive life in harmony with nature." This was an important shift compared to the Stockholm Declaration of the United Nations Conference on the Human Environment of 1972, when this instrument used the notion of "right" as follows in its first principle: "... Both aspects of man's environment, the natural and the man-made, are essential to his well-being and to the enjoyment of basic human rights the right to life itself." 
In the field of human rights, there are some clear differences between "right" and "entitlement", because while a "right" is itself an entitlement associated with a moral or social principle, "entitlement" is referred to a guarantee of access to benefits or enjoyment of some privilege or right. Article 22 of the UDHR clearly recognizes this different perspective as follows: "Everyone, as a member of society, has the right to social security and is entitled to realization, through national effort and international co-operation..." The translation of this provision to Spanish ${ }^{14}$ and French ${ }^{15}$ - two official UN languages - clearly highlights some differences between the notion of "right" and "entitlement". For both languages and in this particular case, this later notion could be translated as "obtain", which translated to a legal English term is an "entitlement".

Independently, whether human beings have a right or are entitled to the enjoyment of peace, human rights and development as set out in the different legal systems, what is clear is that thanks to the reference to "right" everyone should have access to the fruition or benefits derived from the respect and protection of the three UN pillars peace, human rights and development.

\section{ELEMENTS TO WORK IN A MORE INCLUSIVE MANNER}

UNGA Resolution 3201 (S-VI) on the Establishment of a New International Economic Order of 1974, adopted by the General Assembly without a vote, is an important precedent intended to obtain more agreeable solutions in the future based on dialogue, transparency, consensus, inclusiveness and objectivity in very conflicting matters. This case is a good model for other similar processes, such as the right to peace.

Despite that positions can seem absolutely irreconcilable at certain points, delegations could overcome in that time their differences taking into account the following principles, which could be duly taken into account in the future development on the right to peace within the United Nations:

\section{Political will}

It is precisely through such a common political will that the international community can adopt by consensus important documents before the General Assembly, documents that are the product of long hours of consultations, negotiations, compromises and cooperation. A genuine political engagement will be a landmark in the development of true international co-operation (A/PV. 2231, 2.05.1974: para. 94).

These decisions are an expression of the political will of the international community to work together for the establishment of a more balanced and just world (A/PV. 2230, 2.05.1974: para. 93). In this type of process, in which there exists a collective political will to tackle the genuine problems of development, the United Nations is more than ever now emerging as the proper instrument to the solution of the great problems of the day (A/PV. 2230: para. 187).

14 "Toda persona, como miembro de la sociedad, tiene derecho a la seguridad social, y a obtener, mediante el esfuerzo nacional y la cooperación internacional..."

15 "Toute personne, en tant que membre de la société, a droit à la sécurité sociale; elle est fondée à obtenir la satisfaction des droits économiques..." 


\section{Leadership and Dialogue}

The role played by the Chairperson entrusted with drafting a new declarative instrument within the General Assembly is fundamental to progress in the deliberations and to achieving an agreement among all stakeholders based on consensus. To deny that such efforts were constantly preceded by a desire to arrive at a consensus and that the consensus was in fact the result of the session would be to blink away the reality of the lengthy hours of discussions held in the United Nations during weeks preceding formal sessions (A/PV. 2231: para. 54).

\section{Cooperation}

All reservations and differences can in time be ironed out through a spirit of justice and mutual understanding and in that true cooperation which is in the common interest in our world today. In this type of situation the challenge is to accept our mutual dependence and to agree on an agenda for common action to improve the quality of life across the globe. Success cannot be determined by one nation or by one group of nations seeking to impose its will (A/PV. 2229, 1 May 1974: para. 85).

In this type of agreements some delegations will want to dissociate because the text will seem weak and diluted. Nevertheless, in an effort to cooperate, delegations feel that a consensus should be the result of the joint work rather than a confrontation (A/PV. 2231: para. 13).

\section{Realism}

Too often in the past the United Nations has been the forum for unrealistic promises and unfulfilled commitments. The ideal has been substituted for the attainable, and the results have been often no more than increased frustration and disappointment (A/PV. 2229: para. 86). In other words, the international community must relentlessly distinguish between that which is possible and that which is not, so as to proceed in accordance with stages truly accepted by those that have the means to implement them. This simple appeal or, rather, reminder of the laws of genuine international progress does not imply that the international community can disregard the notion of that which is desirable. It is clearly necessary for the United Nations to continue to be a centre for active thought in determining those ideals that are to guide Member States not only in the fields of peace, security and disarmament but also, and increasingly, in determining the conditions in which a more satisfactory economic order ought to be established (A/PV. 2229: para. 176).

\section{Flexibility and tolerance}

Throughout these proceedings the spirit of moderation and conciliation should guide the work. On all sides, the partners to the dialogue, in spite of the reservations of some, displayed their political will to achieve consensus reflecting in its broadest form their agreement on the essential principles for future action and on the ways in which the international community should tackle their future tasks jointly (A/PV. 2231: para. 181).

\section{Common good of humankind}

This type of consensual processes leading to the adoption of new instruments by the General Assembly signifies a milestone in the history of the United Nations. Member 
States demonstrate a spirit of co-operation that is greatly encouraging. They have, from sometimes strongly conflicting positions of interests, made sacrifices with the aim of creating a solid foundation for the forthcoming efforts to design a more just and equitable relationship between nations (A/PV. 2229: para. 124).

The vision of the current world, which is shared by the vast majority of the membership of the Organization, can be seen reflected in the consensus of the General Assembly, for that consensus is the consensus of mankind. Anyone denying that consensus not only seems to be far away from the feelings of the immense majority of the membership of this Organization but also to be wandering even further afield from what is daily becoming world-wide opinion (A/PV. 2229: para. 61).

$$
* * *
$$

In the $17^{\text {th }}$ session of the General Assembly, several delegates expressed concern about submitting the conclusions of the Assembly to the mechanical process of majorities and also emphasized the importance of allowing all delegations to be heard and therefore, adopting the conclusions by consensus. Currently, the notion of consensus is being emphasized in all aspects of the work of the United Nations. In fact, the rule of consensus has been included in the Rules of Procedure of the General Assembly in its Article 104 with regards to financial issues, as follows:

The Special Committee considers that the adoption of decisions and resolutions by consensus is desirable when it contributes to the effective and lasting settlement of differences, thus strengthening the authority of the United Nations...

According to the doctrine and the UN practice, instruments adopted by the General Assembly are usually based on broad agreement. Consensus is important when legal principles are developed, but especially vital for approval of a new legal instrument, since it is the basis of the validity of that law.

The adoption by consensus of peace instruments in the General Assembly has been a clear tendency since the creation of the United Nations. In particular, it should also be recalled that the Declaration on the Promotion among Youth of the Ideals of Peace, Mutual Respect and Understanding between Peoples of 1965, the Declaration on the Protection of Women and Children in Emergency and Armed Conflict of 1974, Declaration on the Participation of Women in Promoting International Peace and Co-operation of 1982 and the Political Declaration on the Peaceful Resolution of Conflicts in Africa of 2013, were adopted by consensus.

Neither the Declaration on Preparation on Societies to Life in Peace of 1978, the Declaration on the Right of Peoples to Peace of 1984 nor the Declaration and Programme of Action on Culture of Peace of 1999 were adopted by the General Assembly with the opposition of regional groups. In fact, both the Declaration on Preparation on Societies to Life in Peace and the Declaration and Programme of Action on Culture of Peace were adopted by consensus, with the exception of the first instrument, which was adopted with only one abstention. On the other hand, the Declaration on the Right of Peoples to Peace obtained the abstention from all Western and European States, but never the vote against.

The problem arises when there are important substantive differences among delegations and the possibility of a broad agreement seems a chimera. A Declaration adopted 
by consensus may even contain contentious elements, which are usually left open to continue working on them in the future. However, this consensus cannot be achieved if sufficiently ambiguous language has not previously been used and States did not express their position on those elements in which it was not possible to reach agreement through a political statement.

In the work of the United Nations, the adoption of the Declaration on the Establishment of a New International Economic Order in 1974 shows how, despite major differences, the consensus among the delegations can be preserved.

This case is a good model for other similar processes, such as the right to peace. Although the UNGA Third Committee of the General Assembly adopted the Declaration on the Right to Peace by majority of its Member States, and not by consensus as desirable, the interpretation of some particular provisions could help to approach positions in the future. In light of previous processes, those elements which could really serve to interpret positively the title and article 1 are the following: political will, dialogue, cooperation, realism, flexibility and tolerance and preservation of the common good of humankind.

An agreement among States and regional groups could not finally be achieved within the HRC and the Third Committee, exclusively because of the lack of agreement on the title and Article 1. However, as indicated by some Group of States, the Declaration has some value because it develops the New Agenda 2030 and also reinforces the three UN pillars - peace and security, development and human rights.

It is strongly desirable for the promotion of peace worldwide to strengthen the positive trend on this matter already initiated in the times of the UN Commission on Human Rights. In particular, some Latin American, African and Asian States, which currently support the right to peace in the United Nations, abstained on this topic at the Commission. ${ }^{16}$ Additionally, it should be taken into account that although some other important States abstained on the right to peace within the HRC - India and Mexico, 2008, their positions positively changed in the past years by supporting the Declaration on the Right to Peace recently adopted by the UNGA Third Committee.

Currently, the Latin American, the African and the Asian group - with the exception of some particular States: Japan and South Korea - positively support the right to peace, which was never the case in the past. In addition, it should be taken into account that an important number of Western States abstained for the first time ever on this topic in the adoption of the Declaration on the Right to Peace in the HRC, the Third Committee and the plenary of the UNGA.

In order to strengthen the positive trend and to move towards a more consensual and inclusive approach using a more ambiguous and vague language in article 1, the ASEAN States and many civil society organizations, have always proposed the notion of the right to enjoy peace, human rights and development. By using the notion of "right", the legislator desired to stress the idea that everyone is entitled to enjoy and access the benefits stemmed from peace, human rights and development, founding pillars of the whole UN system. Denying this access to the three pillars is to deny the same existence of the United Nations.

${ }_{16}$ Res. E/CN.4/2002/L.90, August 2002: Argentina, Brazil, Guatemala, India and Senegal; Res. E/CN.4/2003/L.76, May 2003: Argentina, Chile, Costa Rica and India; Res. E/CN.4/2005/56, April 2005: Argentina, Armenia, Costa Rica, Honduras, India and Mexico. 
Over the last years many delegations have advocated for the idea that the right to peace is closely connected to peace, human rights and development. An explanation of position or an interpretation by States of this particular point on that direction could be one of the possible solutions on this matter.

The problem of the title leads us to the wise reflection contained in William Shakespeare's play Romeo and Juliet, in which Juliet seems to argue that it does not matter that Romeo is from her rival's house of Montague and that he is named "Montague." The poem says:

Tis but thy name that is mine enemy:

What's Montague? It is not hand nor foot,

Nor arm, nor face, nor any other part.

What's in a name? That which we call a rose,

By any other name would smell as sweet.

This reference of universal literature is often used to imply that the names of things do not affect what they really are. In the case of the Declaration on the Right to Peace, the name of this Declaration should not impede its development by consensus, taking into account that the full text was properly negotiated and could obtain the support from all delegations. Therefore, in reference again to Romeo's house, Juliet said that the name of Montague means nothing and they should be together.

In the pursuit of broad agreements in the next future of the Declaration on the Right to Peace within the United Nations, we should recall that for this endeavor there is another personage in international literature, Moliere's bourgeois gentilhomme, who discovered too late that he was speaking prose without knowing. Let no one discover too late that we are making history without knowing it (A/PV. 2231: para. 124).

"Peace is a never ending process... It cannot ignore our differences or overlook our common interests. It requires us to work and live together"

(Oscar Arias, Nobel Peace Prize Laureate and former President of Costa Rica)

\section{BIBLIOGRAPHY}

Eide A. (1999), Article 28, in: The Universal Declaration of Human Rights: a common standard of achievement, (eds.) G. Alfredsson, A. Eide, The Hague-Boston-London.

Garner B. A. (2014), Black's Law Dictionary, Thomson Reuters.

Guillermet Fernandez Ch., Fernández Puyana D. (2014), Analysis of the UNESCO approach to the notions of human rights, peace and development in the context of Culture of Peace, "European Human Rights Law Review", Issue 5, London.

Guillermet Fernandez Ch., Fernández Puyana D. (2015), Assessment of the Right to Peace, "International Journal of Law", Vol. 1, No. 1, Varanasi.

Guillermet Fernandez Ch., Fernández Puyana D. (2016), Analysis and Assessment of the Right to Peace in light of the latest developments at the Human Rights Council, "Eruditio", Vol. 2, No. 1, New York. 
Guillermet Fernandez Ch., Fernández Puyana D. (2015), Building human rights, peace and development within the United Nations, "Russian Law Journal", No. 3, Issue 1, Moscow.

Guillermet Fernandez Ch., Fernández Puyana D. (2014), Contribution of the Commonwealth to the Reinforcement of the Linkage between the Right to Life and Peace, Human Rights and Development within the Human Rights Council, "Journal of Human Rights in the Commonwealth", Vol. 2, No. 1, London.

Guillermet Fernandez Ch., Fernández Puyana D. (2017), Countering terrorism and violent extremism while promoting the right of peoples to peace and security in Africa, "Strathmore Law Journal", Vol. 2, No. 2, Nairobi (Forthcoming).

Guillermet Fernandez Ch., Fernández Puyana D. (2015), Envisioning the right to life and Enjoy Peace, Human Rights and Development within the Human Rights Council, "Przegląd Strategiczny" ("Strategic Review”), No. 8, Poznań.

Guillermet Fernandez Ch., Fernández Puyana D. (2013), From a Culture of Conflict to a Culture of Peace, Human Rights and Development, "Diritti Umani/Peace Human Rights, Special Issue on the Right to Peace", No. 2-3, Human Rights Centre of the University of Padova, UNESCO Chair on human rights, democracy and peace and Region of Veneto, Padova.

Guillermet Fernandez Ch., Fernández Puyana D. (2014), Guerra e pace: il ruolo dei diritti umani e del Costa Rica, "Scienza e Pace. Journal of the Sciences for Peace Interdisciplinary Centre", Vol. 5, No. 1, Pisa.

Guillermet Fernandez Ch., Fernández Puyana D. (2015), La diplomacia multilateral en temas de paz, derechos humanos y desarrollo dentro del sistema de las Naciones Unidas: los Grupos de Trabajo de composición abierta, in: Derecho diplomático y consular: un Enfoque desde las Novedades y Permanencias en el Nuevo Milenio, (ed.) J. L. Collantes González, Barcelona.

Guillermet Fernandez Ch., Fernández Puyana D. (2014), Legal approach to the Chairperson-Rapporteur's draft Declaration in the light of the current debate on the right of peoples to peace, "Italian Yearbook of Human Rights", Brussels.

Guillermet Fernandez Ch., Fernández Puyana D. (2015), Paying real tribute to all victims of war and conflict, Inter Press Service (IPS) News Agency, Section of Opinion, Rome.

Guillermet Fernandez Ch., Fernández Puyana D. (2016), Series of papers published in the journal

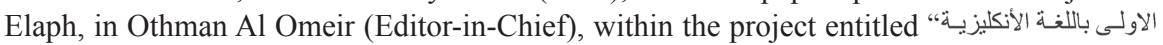
"لقراءة نص الورقة Nations'work”), Elaph Publishing (in partnership with BBC News), London.

Guillermet Fernandez Ch., Fernández Puyana D. (2014), The Right to Live in a Context of Human Rights, Peace and Development. A debate within the Human Rights Council, Policy Paper/ International Catalan Institute for Peace, No. 11, Barcelona.

Guillermet Fernandez Ch., Fernández Puyana D. (2014), The $30^{\text {th }}$ Anniversary of the Declaration on the Right of Peoples to Peace: an opportunity to reinforce the linkage between the right to life and human rights, peace and development, "Peace Forum", Vol. 3, Tokyo.

Guillermet Fernandez Ch., Fernández Puyana D. (2015), The BRICS commitment in the promotion of equality between women and men: analysis from the human rights and peace perspective, "BRICS Law Journal", Vol. 2, No. 2, joint initiative from the Pontifical Catholic University of Sao Paulo (Brazil), Lomonosov Moscow State University (Russia), National Law University Jodhpur (India), Peking University (China) and University of Pretoria (South Africa).

Guillermet Fernandez Ch., Fernández Puyana D. (2015), The ASEAN Human Rights Declaration, the Human Rights Council and the Vienna Declaration and Programme of Action, Indonesian Quarterly, First issue, Vol. 43, No. 1, Yayasan Proklamasi, Centre for Strategic and International Studies, Jakarta (Indonesia). 
Guillermet Fernandez Ch., Fernández Puyana D. (2015), The complementarity of the Security Council and the Human Rights Council in the promotion and protection of the right to life in conflict situation, "Scienza e Pace. Journal of the Sciences for Peace Interdisciplinary Centre", Research Paper, No. 26, Pisa.

Guillermet Fernandez Ch., Fernández Puyana D. (2015), The 70 Anniversary of the creation of the United Nations: giving peace a chance, "Cadmus", Vol. 2, Issue 4, of California.

Guillermet Fernandez Ch., Fernández Puyana D. (2016), The search for consensus and unanimity within the international organizations, "US-China Law Journal", Vol. 13, No. 1, New York.

Guillermet Fernandez Ch., Fernández Puyana D. (2016), Through humanity to peace: Efforts of Red Cross and Red Crescent to create a world free of war and conflict, "International Journal of Humanities and Social Science Research", Vol. 2, No. 1, Delhi.

Guillermet Fernandez Ch., Fernández Puyana D. (2016), The Principles of Transparency and Inclusiveness as Pillars of Global Governance: The BRICS Approach to the United Nations, "BRICS Law Journal", Vol. 2, Issue 2, Moscow.

Guillermet Fernandez Ch., Fernandez Puyana D. (2017), Countering terrorism and violent extremism while promoting the right of peoples to peace and security in Africa, "Strathmore Law Journal", Vol. 1, Nairobi.

Guillermet Fernandez Ch., Fernandez Puyana D. (2017), The adoption of the Declaration on the Right to Peace by the United Nations: a human rights landmark, Peace Human Rights Governance 1 (2), Human Rights Center and University of Padova.

Guillermet Fernandez Ch., Fernandez Puyana D. (2017), The General Assembly adopts the Declaration on the Right to Peace: An opportunity to strengthen the linkage between Peace, Human Rights and Development in the New Millennium, Eruditio, 2(3).

Guillermet Fernandez Ch., Fernandez Puyana D. (2017), Implementing the Declaration on the Right to Peace in the world, "European Human Rights Law Review", Issue 3, London.

Guillermet Fernandez Ch., Perry D. J., Fernández Puyana D. (2015), Health and the right to life in peace: where are the voices of health professionals?, "Health and Human Rights Journal", Vol. 17, Issue 1.

Guillermet Fernandez Ch., Perry D. J., Fernández Puyana D. (2015), Reaching Shared Meaning for Peace, Peace and Health Blog, International Physicians for the Prevention of Nuclear War, Malden.

Guillermet Fernandez Ch., Perry D. J., Fernández Puyana D. (2015), Transforming our World: Reflections on the Sustainable Development Goal for Peace, Blog, Health and Human Rights Journal, Center for Health and Human Rights and Harvard University Press, Massachusetts.

Jiménez Cortes C., Bondia García D., (2010), Actos normativos de las organizaciones internacionales. Actos unilaterales del Estado, in: Derecho internacional: curso general, (eds.) R. Remiro Brotons, R. Riquelme Cortado, E. Orihuela Calatayud, Valencia, Tirant lo Blanch.

Resolution 1860 (2009) Adopted by the Security Council at its 6063 ${ }^{\text {rd }}$ meeting, on 8 January 2009 (2009), S/RES/1860 (2009), New York, 8.01.2009.

Resolution 71/189 of the United Nations General Assembly - Declaration on the right to peace (2016), A/RES/71/189, New York, 19.12.2016.

Resolution 60/251 of the United Nations General Assembly - Human Rights Council (2006), A/RES/60/251, New York, 15.03.2006.

Resolution 48/126 of the United Nations General Assembly - United Nations Year for Tolerance (1993), A/RES/48/126, New York, 20.12.1993.

Schabas W. (2013), The Universal Declaration of Human Rights: the travaux préparatoires, Cambridge. 
The Universal Declaration of Human Rights: a common standard of achievement (2004), (eds.) G. Alfredsson, A. Eide, The Hague.

\section{ANNEX \\ General Assembly Resolution A/RES/71/189, 19 December 2016}

\section{Declaration on the right to peace}

The General Assembly,

Guided by the purposes and principles of the Charter of the United Nations,

Recalling the Universal Declaration of Human Rights, the International Covenant on Civil and Political Rights, the International Covenant on Economic, Social and Cultural Rights and the Vienna Declaration and Programme of Action,

Recalling also the Declaration on the Right to Development, the United Nations Millennium Declaration, the 2030 Agenda for Sustainable Development, including the Sustainable Development Goals, and the 2005 World Summit Outcome,

Recalling further the Declaration on the Preparation of Societies for Life in Peace, the Declaration on the Right of Peoples to Peace and the Declaration and Programme of Action on a Culture of Peace, and other international instruments relevant to the subject of the present declaration,

Recalling the Declaration on the Granting of Independence to Colonial Countries and Peoples,

Recalling also that the Declaration on Principles of International Law concerning Friendly Relations and Cooperation among States in accordance with the Charter of the United Nations solemnly proclaimed the following principles:

that States shall refrain in their international relations from the threat or use of force against the territorial integrity or political independence of any State, or in any other manner inconsistent with the purposes of the United Nations, the principle that States shall settle their international disputes by peaceful means in such a manner that international peace and security and justice are not endangered, the duty not to intervene in matters within the domestic jurisdiction of any State, in accordance with the Charter, the duty of States to co-operate with one another in accordance with the Charter, the principle of equal rights and self-determination of peoples, the principle of sovereign equality of States, the principle that States shall fulfil in good faith the obligations assumed by them in accordance with the Charter,

Reaffirming the obligations of all Member States, as enshrined in the Charter of the United Nations, to refrain in their international relations from the threat or use of force against the territorial integrity or political independence of any State, or in any other manner inconsistent with the purposes of the United Nations, and to settle their international disputes by peaceful means in such a manner that international peace and security, and justice are not endangered,

Acknowledging that the fuller development of a culture of peace is integrally linked to the realization of the right of all peoples, including those living under colonial or other forms of alien domination or foreign occupation, to self-determination enshrined in the Charter of the United Nations and embodied in the International Covenants on Human Rights, as well as in the Declaration on the Granting of Independence to Colonial Countries and Peoples contained in General Assembly resolution 1514 (XV) of 14 December 1960, 
Convinced that any attempt aimed at the partial or total disruption of the national unity and territorial integrity of a State or country or at its political independence is incompatible with the purposes and principles of the Charter, as stated in the Declaration on Principles of International Law concerning Friendly Relations and Cooperation among States in accordance with the Charter of the United Nations, contained in General Assembly resolution 2625 (XXV) of 24 October 1970,

Recognizing the importance of the settlement of disputes or conflicts through peaceful means,

Deeply deploring all acts of terrorism, recalling that the Declaration on Measures to Eliminate International Terrorism recognizes that acts, methods and practices of terrorism constitute a grave violation of the purposes and principles of the United Nations and may pose a threat to international peace and security, jeopardize friendly relations among States, threaten the territorial integrity and security of States, hinder international cooperation and aim at the destruction of human rights, fundamental freedoms and the democratic bases of society, and reaffirming that any acts of terrorism are criminal and unjustifiable regardless of their motivations, whenever and by whomsoever committed,

Stressing that all measures taken in the fight against terrorism must be in compliance with the obligations of States under international law, including international human rights, refugee and humanitarian law, as well as those enshrined in the Charter,

Urging all States that have not yet done so to consider, as a matter of priority, becoming parties to international instruments related to terrorism,

Reaffirming that the promotion and protection of human rights for all and the rule of law are essential to the fight against terrorism, and recognizing that effective counterterrorism measures and the protection of human rights are not conflicting goals but are complementary and mutually reinforcing,

Reaffirming also the determination of the peoples of the United Nations as expressed in the Preamble to the Charter to save succeeding generations from the scourge of war, to reaffirm faith in fundamental human rights, to promote social progress and better standards of life in larger freedom, and to practice tolerance and live together in peace with one another as good neighbours,

Recalling that peace and security, development and human rights are the pillars of the United Nations system and the foundations for collective security and well-being, and recognizing that development, peace and security and human rights are interlinked and mutually reinforcing,

Recognizing that peace is not only the absence of conflict, but also requires a positive, dynamic participatory process where dialogue is encouraged and conflicts are solved in a spirit of mutual understanding and cooperation, as well as socio-economic development is ensured,

Recalling that the recognition of the inherent dignity and the equal and inalienable rights of all members of the human family is the foundation of freedom, justice and peace in the world, and recognizing that peace is promoted through the full enjoyment of all inalienable rights derived from the inherent dignity of all human beings,

Recalling also that everyone is entitled to a social and international order in which the rights and freedoms set forth in the Universal Declaration of Human Rights can be fully realized,

Recalling the world commitment to eradicate poverty and promote sustained economic growth, sustainable development and global prosperity for all and the need to reduce inequalities within and among countries, 
Recalling the importance of prevention of armed conflict in accordance with the purposes and principles of the Charter and of the commitment to promote a culture of prevention of armed conflict as a means of effectively addressing the interconnected security and development challenges faced by peoples throughout the world,

Recalling that the full and complete development of a country, the welfare of the world and the cause of peace require the maximum participation of women on equal terms with men in all fields,

Reaffirming that since wars begin in the minds of human beings, it is in the minds of human beings that the defences of peace must be constructed and recalling the importance of the settlement of disputes or conflicts through peaceful means,

Recalling the need for strengthened international efforts to foster a global dialogue for the promotion of a culture of tolerance and peace at all levels, based on respect for human rights and diversity of religions and beliefs,

Recalling further that development assistance and capacity-building based on the principle of national ownership in post-conflict situations should restore peace through rehabilitation, reintegration and reconciliation processes involving all those engaged, and recognizing the importance of peacemaking, peacekeeping and peacebuilding activities of the United Nations for the global pursuit of peace and security,

Recalling that the culture of peace and the education of humanity for justice and liberty and peace are indispensable to the dignity of human beings and constitute a duty that all nations must fulfil in a spirit of mutual assistance and concern,

Reaffirming that the culture of peace is a set of values, attitudes, traditions and modes of behaviour and ways of life, as identified in the Declaration on a Culture of Peace, and that all this should be fostered by an enabling national and international environment conducive to peace,

Recognizing the importance of moderation and tolerance as values contributing to the promotion of peace and security,

Recognizing also the important contribution that civil society organizations can make in building and preserving peace, as well as in strengthening a culture of peace,

Stressing the need for States, the United Nations system and other relevant international organizations to allocate resources to programmes aimed at strengthening the culture of peace and upholding human rights awareness through training, teaching and education,

Stressing also the importance of the contribution of the United Nations Declaration on Human Rights Education and Training to the promotion of a culture of peace,

Recalling that respect for the diversity of cultures, tolerance, dialogue and cooperation, in a climate of mutual trust and understanding, are among the best guarantees of international peace and security,

Recalling also that tolerance is respect, acceptance and appreciation of the rich diversity of our world's cultures, our forms of expression and ways of being human, as well as the virtue that makes peace possible and contributes to the promotion of a culture of peace,

Recalling further that the constant promotion and realization of the rights of persons belonging to national or ethnic, religious and linguistic minorities as an integral part of the development of a society as a whole and within a democratic framework based on the rule of law would contribute to the strengthening of friendship, cooperation and peace among peoples and States, 
Recalling the need to design, promote and implement at the national, regional and international levels strategies, programmes and policies, and adequate legislation, which may include special and positive measures, for furthering equal social development and the realization of the civil and political, economic, social and cultural rights of all victims of racism, racial discrimination, xenophobia and related intolerance,

Recognizing that racism, racial discrimination, xenophobia and related intolerance, where they amount to racism and racial discrimination are an obstacle to friendly and peaceful relations among peoples and nations, and are among the root causes of many internal and international conflicts, including armed conflicts,

Inviting solemnly all stakeholders to guide themselves in their activities by recognizing the high importance of practicing tolerance, dialogue, cooperation and solidarity among all human beings, peoples and nations of the world as a means to promote peace; to that end, present generations should ensure that both they and future generations learn to live together in peace with the highest aspiration of sparing future generations the scourge of war,

\section{Article 1}

Everyone have the right to enjoy peace such that all human rights are promoted and protected and development is fully realized.

\section{Article 2}

States should respect, implement and promote equality and non-discrimination, justice and the rule of law and guarantee freedom from fear and want as a means to build peace within and between societies.

\section{Article 3}

States, the United Nations and specialized agencies should take appropriate sustainable measures to implement the present Declaration, in particular the United Nations Educational, Scientific and Cultural Organization. International, regional, national and local organizations and civil society are encouraged to support and assist in the implementation of the present Declaration.

\section{Article 4}

International and national institutions of education for peace shall be promoted in order to strengthen among all human beings the spirit of tolerance, dialogue, cooperation and solidarity. To this end, the University for Peace should contribute to the great universal task of educating for peace by engaging in teaching, research, post-graduate training and dissemination of knowledge.

\section{Article 5}

Nothing in the present Declaration shall be construed as being contrary to the purposes and principles of the United Nations. The provisions included in this Declaration are to be understood in the line of the Charter of the United Nations, the Universal Declaration of Human Rights and relevant international and regional instruments ratified by States. 


\begin{abstract}
War and peace perpetually alternate and peace is always seen as an endless project, even a dream, to be realised in brotherhood by everyone all over the earth. Present generations should ensure that both they and future generations learn to live together in peace with the highest aspiration of sparing future generations the scourge of war. The UN Charter is the most solemn pact of peace in history, which lays down on the necessary basic principles for an enduring peace. Recently, in the context of the joint effort in the recognition of the high importance of practicing tolerance, dialogue, cooperation and solidarity among all human beings, peoples and nations, the General Assembly has raised the voice of victims to strongly condemn war and to openly reiterate their inalienable right to enjoy peace such that all human rights are promoted and protected and development is fully realized. The aim is to present activities of the General Assembly focused on the adoption of the Declaration on the right to peace.
\end{abstract}

Keywords: peace, human rights, development, General Assembly, Human Rights Council, war, right to peace, UN Charter, international law

\title{
W POSZUKIWANIU POROZUMIENIA DOTYCZĄCEGO DEKLARACJI W SPRAWIE PRAWA DO POKOJU W RAMACH ORGANIZACJI NARODÓW ZJEDNOCZONYCH
}

\section{STRESZCZENIE}

Karta Narodów Zjednoczonych jest najważniejszym paktem pokoju w historii świata, wskazującym podstawowe zasady utrzymania pokoju. W ostatnich latach widoczne jest dążenie społeczności międzynarodowej, podkreślające znaczenie tolerancji, dialogu, współpracy i solidarności między jednostkami, ludami i narodami. Dążenie to przejawia się między innymi w działaniach Zgromadzenia Ogólnego ONZ, które potępia wojnę i opowiada się za uznaniem prawa do pokoju jako prawa człowieka i zabiega o jego promowanie, ochronę i rozwój. Celem artykułu jest ukazanie działań Zgromadzenia Ogólnego, skierowanych na przyjęcie Deklaracji w sprawie prawa do pokoju.

Słowa kluczowe: pokój, prawa człowieka, rozwój, Zgromadzenie Ogólne, Rada Praw Człowieka, wojna, prawo do pokoju, Karta Narodów Zjednoczonych, prawo międzynarodowe 
